\title{
COMPUTER-AIDED VOICE PITCH THERAPY IN AURALLY IMPAIRED STUDENTS
}

\author{
Katarzyna Plutecka, Jolanta Zielinska \\ Pedagogical University of Cracow, Special Education Institute, Cracow, Poland
}

Corresponding author: Katarzyna Plutecka, Pedagogical University of Cracow, Special Education Institute, Ingardena 4 Str., 30-060 Cracow, Poland, e-mail: kaplutecka@interia.pl

\begin{abstract}
Background: The aim was to measure, evaluate, and improve voice pitch characteristics (measured on the basis of the average fundamental frequency, Fx), in students aged 10-12 who had substantial or severe hearing loss and were fitted with hearing aids. Two core questions were asked: (i) Is therapy using the PCLX Laryngograph Processor effective? (ii) Which factors affect the outcome of therapy?
\end{abstract}

Material and methods: Therapy based on a multimedia computer workstation using the PCLX Laryngograph Processor is proposed, a system capable of visualizing voiced speech using electroglotography. The study is constructed as a pedagogical experiment, using parallel groups and Mill's method of difference.

Results: Pretest results show that, prior to therapy sessions, both groups (experimental and control) were largely equivalent with respect to voice pitch characteristics. In total, 49 students exhibited anomalous voice pitch characteristics while 14 cases could be described as unstable (with pitch sometimes correct, but not consistently so). Correlations between concomitant variables and the effectiveness of the therapeutic process were found. In particular, intelligence and visual-motor coordination played a significant role. Variables such as learning speed, working memory capacity, forgetfulness, time since onset of hearing loss, and degree of aural impairment seem to be less important. Improvements appeared to depend on the subject's family environment and were largely independent of age and degree of hearing loss.

Conclusions: The research has shown that in most aurally impaired subjects voice pitch is too high and needs to be corrected. The proposed therapy is shown to be highly effective, producing persistent long-term improvements, especially in the case of younger students.

Key words: therapy of voice $\bullet$ Laryngograph Processor $\bullet$ impaired students

\section{TERAPIA DE TONO DE VOZ ASISTIDA POR ORDENADOR DE ESTUDIANTES CON TRASTORNOS DEL HABLA}

\section{Resumen}

Antecedentes: El objetivo del trabajo fue la evaluación, análisis y mejora de las características del tono de voz (evaluación sobre la base de la frecuencia media, Fx) de estudiantes de 10-12 años que tenían una pérdida auditiva considerable o profunda y llevaban audífonos. Se hicieron dos preguntas: (i) ¿Es efectiva la terapia con uso de Laryngograph Processor PCLX? (ii) ¿Qué factores influyeron en el resultado de la terapia?

Material y métodos: Se propuso realizar pruebas sobre la base de Laryngograph Processor PCLC, un sistema que permite la visualización del habla con ayuda de electrocardiografía. La prueba es un experimento pedagógico con uso de grupos paralelos y métodos de diferencia única de Mill.

Resultados: Los resultados antes de la terapia demostraron que los dos grupos (de prueba y de control) eran parecidos en cuanto a las características de los todos de sonidos expresados. En general, 49 estudiantes mostraban características atípicos de tonos de sonidos expresados, mientras que 14 casos se calificaron como inestables (el tono de la voz no siempre era correcto). Se observaron correlaciones entre las variables coexistentes y la eficacia del proceso de la terapia. Un papel de gran importancia lo desempeñó la inteligencia y el estado visomotor. Menos importantes resultaron variables como el tiempo de aprender, la capacidad de la memoria de trabajo, la tendencia a olvidar, el tiempo desde los primeros síntomas de la pérdida auditiva y el nivel del trastorno del habla. El progreso en los pacientes dependía de su entorno familiar, mientras que no dependía de la edad y del nivel de la falta auditiva. 
Conclusiones: La prueba demostró que en estudiantes con los trastornos auditivos más graves los sonidos son demasiado agudos y requieren ser corregidos. La terapia realizada resultó eficaz y los resultados obtenidos eran estables y duraderos sobre todo en estudiantes menores.

Palabras clave: prueba auditiva • Laryngograph Processor • irregularidades médicas en estudiantes

\section{КОМЬЮТЕРНО-УПРАВЛЯЕМАЯ ТЕРАПИЯ ВЫСОТЫ ГОЛОСА У УЧЕНИКОВ С НАРУШЕНИЯМИ РЕЧИ}

\section{Изложение}

Фон: Целью настоящей работы являлась оценка, анализ и улучшение свойств высоты голоса (оценка на основании средней частоты, Fx) у учеников в возрасте 10-12 лет, со значительной или глубокой тугоухостью, которые носили слуховые аппараты. Задавались два основных вопроса: (и) Эффективна ли терапия с применением Laryngograph Processor PCLX? (2) Какие факторы повлияли на результаты терапии?

Материал и методы: Предложено провести исследования на основании Laryngograph Processor PCLX, системы, позволяющей визуализировать голосовую речь с помощью электроглотографии. Это исследование является педагогическим экспериментом с использованием параллельных групп и канона единственного различия Милля.

Результаты: Перед терапией результаты показывали, что обе группы (испытательная и контрольная) были очень похожи, беря во внимание свойства высоты произносимых звуков. 49 учеников проявляло нетипичные свойства высоты произносимых звуков, тогда как 14 случаев были описаны как нестабильные (высота звуков не всегда была правильной). Была замечена взаимосвязь между совместно существующими переменными и эффективностью процесса терапии. Особенно важную роль сыграла сообразительность и зрительно-моторная координация. Менее важными оказались переменные, такие как скорость обучения, вместительность рабочей памяти, забывчивость, время от первых признаков тугоухости, а также степень нарушеий речи. Прогресс у пациента зависел от его семейной среды, но он не зависел от возраста и степени тугоухости.

Итоги: Исследование показало, что у учеников с тяжелыми нарушениями речи, звуки являются слишком высокими и требуют регулировки. Проведенная терапия оказалась эффективной, а достигнутые результаты - стабильные и долговременные, особенно у младших учеников.

Ключевые слова: исследование голоса • Laryngograph Processor • медицинские нарушения у учеников

\section{KOMPUTEROWO WSPOMAGANA TERAPIA WYSOKOŚCI GŁOSU U UCZNIÓW Z ZABURZENIAMI MOWY}

\section{Streszczenie}

Tło: Celem pracy była ocena, analiza i polepszenie cech wysokości głosu (ocena na podstawie średniej częstotliwości, Fx) u uczniów w wieku 10-12 lat, którzy mieli znaczny lub głęboki niedosłuch i nosili aparaty słuchowe. Zadawano dwa podstawowe pytania: (i) Czy terapia z użyciem Laryngograph Processor PCLX jest efektywna? (ii) Jakie czynniki wpłynęły na wynik terapii?

Materiał i metody: Zaproponowano przeprowadzenie badania w oparciu o Laryngograph Processor PCLX, system umożliwiający wizualizację mowy głosowej za pomocą elektroglotografii. Badanie to jest eksperymentem pedagogicznym $\mathrm{z}$ wykorzystaniem grup paralelnych oraz kanonu jedynej różnicy Milla.

Wyniki: Wyniki przed terapią wskazywały, że obie grupy (badawcza i kontrolna) były bardzo podobne w kwestiach cech wysokości wypowiadanych dźwięków. Ogółem 49 uczniów przejawiało nietypowe cechy wysokości wypowiadanych dźwięków, natomiast 14 przypadków opisano jako niestabilne (wysokość dźwięków nie zawsze była prawidłowa). Zaobserwowano korelacje pomiędzy współistniejącymi zmiennymi i efektywnością procesu terapii. Szczególnie istotną rolę odegrała inteligencja i stan wizualno-ruchowy. Mniej ważne okazały się zmienne takie jak szybkość uczenia się, pojemność pamięci roboczej, zapominanie, czas od pierwszych objawów niedosłuchu oraz stopień zaburzeń mowy. Postęp u pacjenta zależał od jego środowiska rodzinnego, natomiast nie zależał od wieku i stopnia niedosłuchu

Wnioski: Badanie wykazało, że u uczniów z najpoważniejszymi zaburzeniami mowy, dźwięki są zbyt wysokie i wymagają skorygowania. Przeprowadzona terapia okazała się efektywna, a osiągnięte wyniki były stabilne i trwałe szczególnie u młodszych uczniów.

Słowa kluczowe: badanie głosu • Laryngograph Processor • nieprawidłowości medyczne u uczniów 


\section{Background}

Aural impairment hampers the development of certain language-mediated skills. One of the basic requirements of effective communication is proper articulation and aural perception. Voiced speech can only be properly and fully interpreted if it is correctly formed. Important natural aspects of speech include timbre, volume, and intonation. The fundamental frequency of the voice $(\mathrm{Fx})$ - both its average value and range - is also important. The most frequently applied method of determining this frequency is through oscillographic analysis of the subject's speech. This process results in a graph which is free of any numerical processing artifacts and represents a complete description of the subject's voice. Unfortunately, such graphs are typically "oversaturated" with information and therefore difficult to process, requiring substantial experience on the part of the researcher. Attempting to determine the basic frequency on the basis of an oscillogram is prone to computational bias, and while the outcome is usually sufficiently accurate for data obtained from healthy individuals, "pathological" input often results in incorrect results. Such aspects must be taken into account when performing analysis. Additionally, isolated phonemes require different methods of analysis than entire words or sentences. A common issue when determining the basic frequency of a pathological voice is to assume that $F_{0}$ is equal to one of its subharmonics (typically $F_{0} / 2$ ), or to equate it to one of its formants (whether first- or higher-order). When dealing with very low- or high-pitched voices it is sometimes possible to validate the result using a low-bandwidth spectrogram, although this requires good knowledge of phonetics and acoustics.

Logopedic and phoniatric studies reveal that aurally impaired students are usually incapable of adjusting their own voice pitch. This is why such students are often prone to audiogenic dysphonia and persistent reinforcement of anomalous conditions within their speech organ (usually the larynx). Aurally impaired subjects may suffer from articulation disorders, including falsetto, hard, atonal, muted, nasal, or guttural speech; incorrect pitch (whether too high or too low); monotonous speech; or a tendency to exclaim [1-9]. Modern information technologies enable researchers to visualize voiced speech and analyze the action of the speech organ in a way which permits diagnosis and assists in the development of correct vocal patterns in impaired students. An example of this evolution is the PCLX Laryngograph Processor, which has wide applicability in diagnosing speech defects and teaching proper articulation to subjects whose phonic problems result from auditory disability.

The key aim of the presented research was to assess, evaluate, and improve voice pitch characteristics in students who had substantial or severe perceptive hearing loss by employing therapy based on the PCLX Laryngograph Processor (and to prove that the therapy was effective). The second research challenge was to assess to what extent different variables (identified during the experiment) affected the outcome of therapy in aurally handicapped subjects.

\section{Material and methods}

The study involved applying multimedia IT tools to evaluate and analyse vocal patterns, referring in particular to previous experience of Polish language analysts [2]. This decision acknowledges the phonological and phonetic differences between languages - although the use of laryngographic tools to study speech defects in aurally impaired individuals is the focus of many researchers from around the world [10-12].

The independent variable in the presented experimental study was the visualization method for voiced speech. Visualization was performed with a multimedia workstation used for corrective, rehabilitation-oriented speech exercises. The key aspect of this variable was its set of technical capabilities resulting from the use of the PCLX Laryngograph Processor. The dependent variable was voice pitch and speech quality in aurally impaired children. The study also involved several concomitant variables with potential impact upon the outcome of therapy sessions - including learning speed, working memory capacity, forgetfulness, intelligence, visual-motor coordination, subject age, time of onset and degree of hearing loss, as well as family environment. Learning speed, forgetfulness, and memory capacity were determined using a custom tool devised for a previous diagnostic study involving school-age children [2]. Intelligence was assessed using the Leiter International Performance Scale for children aged 2-18, Wechlser's Revised Intelligence Scale for Children (WISC-R), Raven's test, and Benton's Visual Retention Test. The Bender-Gestalt test was used to determine visual-motor coordination, employing Mieczyslaw Choynowski’s test sheet.

The study group consisted of 60 students aged 10-12 with significant or severe bilateral prelingual perceptive hearing loss, fitted with non-implanted hearing aids. Details of the study group are further presented in Table 1.

Table 1 shows that the study group was mostly comprised of students with severe hearing loss (75\%) but otherwise free of disabilities (98.2\%), living in the countryside $(61.5 \%)$, and whose parents had mostly vocational $(50.1 \%)$ or primary $(30.4 \%)$ education. Most students had been subjected to early rehabilitation (89.5\%) and had regular contacts with individuals not affected by hearing loss $(81.3 \%)$.

The study assumed the form of a pedagogical experiment, conducted using parallel groups and Mill's method of difference. The study group (60 students) was divided into the experimental group (30 students) and the control group (30 students). Both groups were subjected to initial and final assessment. Assignment of students to groups was performed in such a way as to ensure equal distribution of concomitant variables, as shown in Table 2.

In addition, the groups were balanced with respect to student voice pitch by comparing the average fundamental frequency for each subject (this frequency was determined using sample words and sentences, as well as Voice Profile data provided by the Speech Studio software bundled with the PCLX Laryngograph Processor). Table 3 highlights the equivalence of both groups with respect to voice pitch.

The study involved the following research tools: (i) voice examination sheets listing words and sentences; (ii) answer sheets from psychologist and school counselor interviews. 
Table 1. Percentage breakdown of the study group $(n=60)$

\begin{tabular}{|c|c|c|}
\hline \multirow{3}{*}{ Residence } & village & $61.5 \%$ \\
\hline & town & $19.4 \%$ \\
\hline & city & $19.1 \%$ \\
\hline \multirow{4}{*}{ Parents' education } & primary & $30.4 \%$ \\
\hline & vocational training & $50.1 \%$ \\
\hline & high school diploma & $17.3 \%$ \\
\hline & university degree & $2.2 \%$ \\
\hline \multirow{2}{*}{ Contact with individuals not affected by hearing loss } & yes & $81.3 \%$ \\
\hline & no & $18.7 \%$ \\
\hline \multirow{2}{*}{ Early rehabilitation } & yes & $89.5 \%$ \\
\hline & no & $10.5 \%$ \\
\hline \multirow{2}{*}{ Degree of hearing loss } & significant & $25.0 \%$ \\
\hline & severe & $75.0 \%$ \\
\hline \multirow{2}{*}{ Other disabilities } & yes & $1.8 \%$ \\
\hline & no & $98.2 \%$ \\
\hline
\end{tabular}

Table 2. Equivalence of the experimental group and the control group in terms of concomitant variables $(n=60)$

\begin{tabular}{|c|c|c|c|c|c|c|}
\hline \multirow{2}{*}{$\begin{array}{l}\text { Concomitant } \\
\text { variable }\end{array}$} & \multicolumn{2}{|c|}{ Experimental group } & \multicolumn{2}{|c|}{ Control group } & \multirow{2}{*}{$\begin{array}{c}\text { Student's } \\
t \text {-test }\end{array}$} & \multirow{2}{*}{$\begin{array}{c}\text { Confidence } \\
\text { level } \\
p\end{array}$} \\
\hline & $\begin{array}{c}\text { Average } \\
\mathbf{X}\end{array}$ & $\begin{array}{c}\text { Standard } \\
\text { deviation S }\end{array}$ & $\begin{array}{c}\text { Average } \\
\mathrm{X}\end{array}$ & $\begin{array}{c}\text { Standard } \\
\text { deviation S }\end{array}$ & & \\
\hline Learning speed & 0.621 & 0.186 & 0.598 & 0.174 & 1.061 & 0.001 \\
\hline Working memory capacity & 0.511 & 0.230 & 0.491 & 0.222 & 2.768 & 0.01 \\
\hline Forgetfulness & 0.158 & 0.181 & 0.167 & 0.187 & 1.212 & 0.001 \\
\hline Intelligence & 0.769 & 0.675 & 0.760 & 0.682 & 0.098 & 0.001 \\
\hline Visual-motor coordination & 0.697 & 0.701 & 0.707 & 0.722 & 2.001 & 0.001 \\
\hline Age & 0.965 & 0.243 & 0.942 & 0.248 & 0.879 & 0.001 \\
\hline Time since onset of hearing loss & 0.891 & 0.451 & 0.883 & 0.441 & 1.678 & 0.001 \\
\hline Degree of hearing loss & 0.932 & 0.621 & 0.931 & 0.615 & 3.312 & 0.01 \\
\hline Family environment & 0.372 & 0.131 & 0.368 & 0.136 & 1.531 & 0.001 \\
\hline
\end{tabular}

Table 3. Assessment of the equivalence of the experimental and control group with respect to average frequency of voice $(n=60)$

\begin{tabular}{|c|c|c|c|c|c|c|}
\hline \multirow{2}{*}{ Average voice frequency } & \multicolumn{2}{|c|}{ Experimental group } & \multicolumn{2}{|c|}{ Control group } & \multirow{2}{*}{$\begin{array}{c}\text { Student's } \\
t \text {-test }\end{array}$} & \multirow{2}{*}{$\begin{array}{c}\text { Confidence } \\
\text { level } \\
p\end{array}$} \\
\hline & $\mathbf{N}$ & $\%$ & $\mathbf{N}$ & $\%$ & & \\
\hline Below $260 \mathrm{~Hz}$ & 3 & 0.230 & 2 & 0.174 & 3.062 & 0.001 \\
\hline $260-350 \mathrm{~Hz}$ & 8 & 0.186 & 6 & 0.203 & 2.991 & 0.01 \\
\hline Above $350 \mathrm{~Hz}$ & 19 & 0.260 & 22 & 0.216 & 1.986 & 0.05 \\
\hline
\end{tabular}

Speech therapy sessions in the experimental group focused on achieving the correct voice pitch and employed the PCLX Laryngograph Processor software interface called PC Pitch Target, which is shown in Figure 1. The top window displays the correct pitch pattern while the bottom (active) window shows the current student input.
The study was divided into three stages: initial assessment, core study, and longitudinal study. The goal of initial assessment was to validate the basic assumptions of the presented research into voice pitch therapy using IT tools, formulate research hypotheses, and fine-tune the research procedure. The core study followed the research procedure 


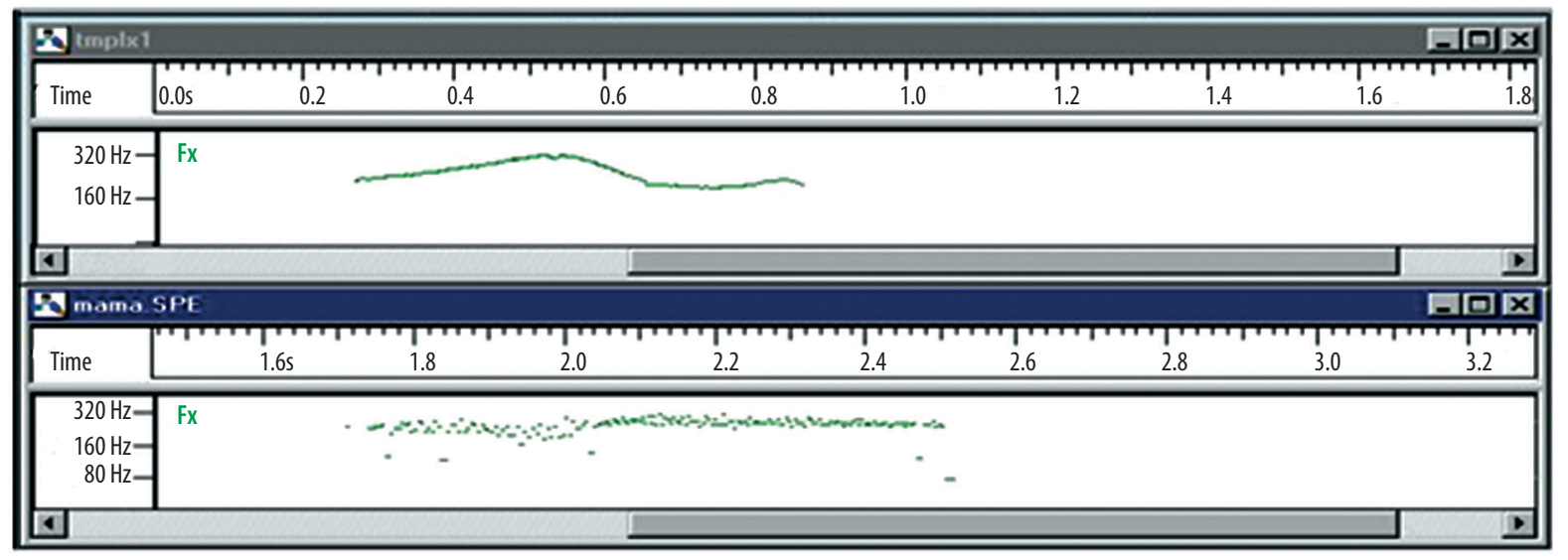

Figure 1. The PC Pitch Target tool used in voice pitch training

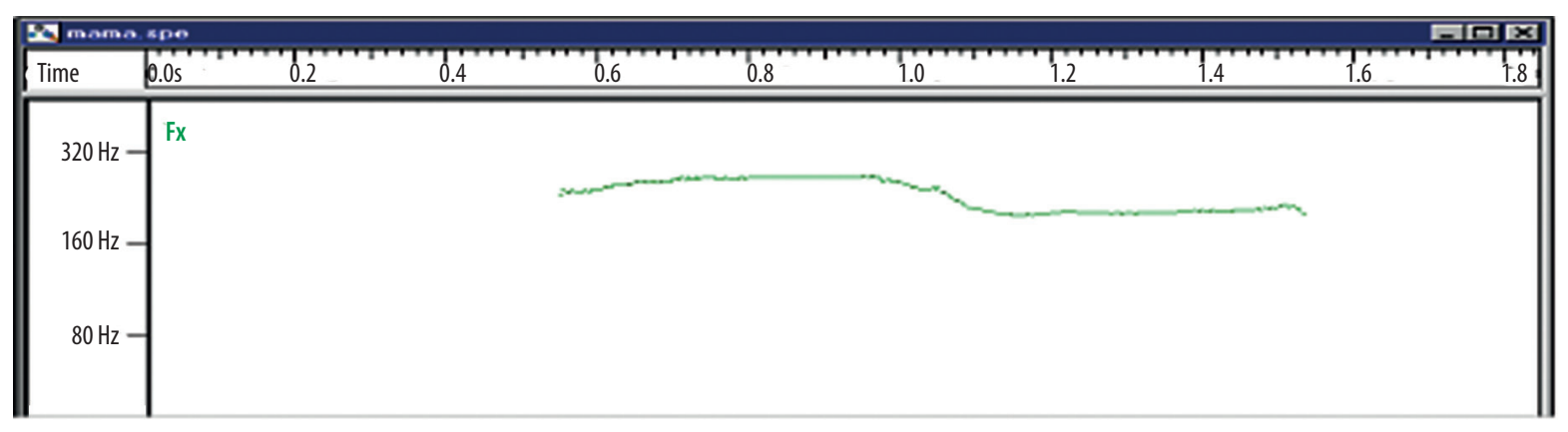

Figure 2. Visual representation of the test subject's fundamental frequency of voice (Fx) (qualitative assessment)

and took the form of a pedagogical experiment (guided by pretest results) involving a study group and a control group. The experimental group was subjected to the therapeutic process devised as part of the experiment, with the goal of improving articulation parameters. In parallel, a set of stimulating and corrective exercises were carried out, enabling subjects to train their voiced speech. Experimental group sessions were carried out on a bi-weekly basis over a period of 3 months. Each session lasted 30 minutes. Phoniatric exercises were adjusted to match the individual needs of each student, depending on his/her prior diagnosis, with a focus on achieving the correct fundamental frequency of voice. A suitable presentation method was selected for each type of language resource in order to make it representative of voice pitch, understandable to aurally impaired students, and easily interpretable by the therapy supervisor. Presentation methods included logotoms; onomatopoeias; bi- and multi-syllabic words; and statements, questions, and commands (conveying expressiveness). Phonemes were presented in the order in which they are typically introduced during a child's vocal development, starting with vowels, through nasal consonants $(\mathrm{m}, \mathrm{n})$ to affricates (c, dz, cz, dż, ć, dź), semivowels (ą, ę), and sonorants $(\mathrm{l}, \mathrm{r})$, enabling the student to achieve and maintain the correct pitch. Self-improvement exercises involved the use of the PC Pitch Target tool, which displays two similar images on the computer screen, presenting fundamental frequency $(\mathrm{Fx})$ changes as a function of time. One image showed an articulation pattern obtained from an unimpaired child of equal age to the test subject, while the other image visualized the corresponding pattern of the subject's own voice. Each analysis was stored in computer memory.

The following two images present the diagnostic capabilities of the IT tool applied in our study. These include visual representation of the fundamental frequency of voice (Fx), a profile showing the average and peak frequencies, as well as numerical deviations indicating irregular function of the vocal folds.

The core study was performed in stages and consisted of voice pitch pretests and posttests performed in both groups (experimental and control). Assessing the persistence of any positive changes brought about by therapy sessions required a longitudinal study, carried out 3 months after the conclusion of the experiment. The longitudinal study included a test performed in both groups to determine what changes in voice pitch had been achieved. Its results were crucial to determining the effectiveness of the experimental therapy sessions.

\section{Results}

The presented research leads to a number of conclusions regarding the diagnostic and therapeutic benefits of the proposed voice pitch therapy. Results are summarized in Table 4. 


\begin{tabular}{|c|c|c|c|c|c|}
\hline Fama.spe:2 & & & & & 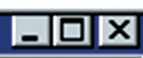 \\
\hline & & Report-Vo & Analysis & & \\
\hline & No. Sapmles & 8 & Duration & $0.714 \mathrm{~s}$ & \\
\hline & Minimal FX & $194.43 \mathrm{~Hz}$ & Maximal FX & $211.95 \mathrm{~Hz}$ & \\
\hline & Average FX & $203.16 \mathrm{~Hz}$ & S.D. FX & $5.08 \mathrm{~Hz}$ & \\
\hline & Minimal QX & $36.28 \%$ & Maximal QX & $47.27 \%$ & \\
\hline & Average QX & $42.47 \%$ & S.D. QX & $2.19 \%$ & \\
\hline & Jiiter First & $2.16 \%$ & Jiiter Second & $0.64 \%$ & \\
\hline & Shimmer+ & $24.34 \%$ & Shimmer- & $-15.69 \%$ & \\
\hline
\end{tabular}

Figure 3. Vocal profile describing the subject's voice pitch (quantitative assessment)

Table 4. Results of core and longitudinal analysis of voice pitch characteristics in aurally impaired students

\begin{tabular}{|c|c|c|c|c|c|c|c|c|}
\hline \multirow{4}{*}{$\begin{array}{l}\text { Subject } \\
\text { voice } \\
\text { pitch }\end{array}$} & \multicolumn{8}{|c|}{ Group } \\
\hline & \multicolumn{3}{|c|}{ Experimental group } & \multirow{3}{*}{$\begin{array}{c}\text { Student's } \\
t \text {-test }\end{array}$} & \multicolumn{3}{|c|}{ Control group } & \multirow{3}{*}{$\begin{array}{c}\text { Student's } \\
t \text {-test }\end{array}$} \\
\hline & \multicolumn{2}{|c|}{ Core study } & \multirow{2}{*}{$\begin{array}{c}\begin{array}{c}\text { Longitudinal } \\
\text { study }\end{array} \\
\text { Final } \\
\text { results }\end{array}$} & & \multicolumn{2}{|c|}{ Core study } & \multirow{2}{*}{$\begin{array}{c}\begin{array}{c}\text { Longitudinal } \\
\text { study }\end{array} \\
\begin{array}{c}\text { Final } \\
\text { results }\end{array}\end{array}$} & \\
\hline & $\begin{array}{l}\text { Pretest } \\
\text { results }\end{array}$ & $\begin{array}{l}\text { Posttest } \\
\text { results }\end{array}$ & & & $\begin{array}{l}\text { Pretest } \\
\text { results }\end{array}$ & $\begin{array}{l}\text { Posttest } \\
\text { results }\end{array}$ & & \\
\hline Correct & $10 \% \quad(3)$ & $70 \%(21)$ & $63 \%(19)$ & 5.378 & $7 \% \quad(2)$ & $7 \% \quad(2)$ & $7 \% \quad(2)$ & 1.134 \\
\hline Borderline & $27 \% \quad(8)$ & $17 \% \quad(5)$ & $20 \%$ & 7.353 & $20 \% \quad(6)$ & $33 \%(10)$ & $27 \% \quad(8)$ & 1.431 \\
\hline Anomalous & $63 \%(19)$ & $13 \% \quad(4)$ & $17 \% \quad(5)$ & 8.680 & $73 \%(22)$ & $60 \%(18)$ & $66 \%(20)$ & 1.098 \\
\hline
\end{tabular}

Pretest results are relevant from a diagnostic point of view, while posttest results reveal the effectiveness of the proposed therapeutic approach. The longitudinal study allows us to assess the long-term persistence of results. As shown in Table 4, at the outset of the study 19 experimental group subjects $(63 \%)$ exhibited voice pitch anomalies (pitch too high; sometimes even offscale high). There were 8 cases (27\%) which could be considered borderline, while only 3 (10\%) were indicative of correct pitch. The corresponding control group results were as follows: 22 cases of anomalous pitch (73\%); 6 borderline cases $(20 \%)$, and 2 cases of correct pitch (7\%). So prior to therapy sessions both groups (experimental and control) were largely equivalent with respect to voice pitch characteristics. Clearly, a large majority of subjects exhibited incorrect (usually too high) pitch.

Posttest results in the experimental group revealed significant improvements, with 21 students (70\%) achieving correct pitch and 5 more (17\%) qualifying as borderline, with only 5 cases $(17 \%)$ of persistent anomalous pitch. The control group did not achieve similar progress: 18 students (60\%) still exhibited anomalous pitch, with 10 more borderline cases (33\%) and only 2 cases (7\%) of correct pitch.

The value of Student's $t$-function revealed substantial statistical differences between pretest and posttest results in the experimental group. A similar assessment was carried out in the control group (i.e. for students not subjected to experimental therapy sessions). Results of articulation tests involving control group subjects indicate that no significant improvement was observed over a period of 6 months, as evidenced by Student's $t$-function value for dependent groups.

Regarding concomitant variables and their influence on the effectiveness of our therapeutic process, some correlations have been noted and listed in Table 5 .

\section{Discussion}

During laryngographic exercises it was noted that, if initially there was a very low articulation volume (i.e. practically inaudible speech), corrective exercises led to a very specific sequence of changes. Voice pitch frequency increased rapidly before stabilizing at a set level specific to the subject. A different situation occurred if the initial pitch was too high: in such cases frequency decreased gradually and the pitch slowly converged to the desired level. At the end of the experiment $70 \%$ of students were able to attain normal pitch - although a gradually fading upward trend has subsequently been noted, especially in situations involving phonemes that are difficult to articulate (such as nasals and sonorants). The longitudinal study revealed correct voice pitch in $63 \%$ of subjects (i.e. $7 \%$ fewer than in the posttest). Changes in pitch appeared to be the most persistent among the youngest students (aged 10), 
Table 5. Effectiveness of the therapeutic procedure with regard to concomitant variables (values indicate aggregate improvement in skill)

\begin{tabular}{llc}
\hline \multicolumn{1}{c}{ Concomitant variable } & Relevance & Classification \\
\hline Learning speed & $r=0.011$ & irrelevant \\
\hline Working memory capacity & $r=0.031$ & irrelevant \\
\hline Forgetfulness & $r=0.001$ & irrelevant \\
\hline Intelligence & $r=0.87$ & very highly relevant \\
\hline Visual-motor coordination & $r=0.69$ & highly relevant \\
\hline Age & $r=0.019$ & irrelevant \\
\hline Time since onset of hearing loss & $r=0.006$ & irrelevant \\
\hline Degree of hearing loss & $r=0.003$ & irrelevant \\
\hline Family environment & $r=0.104$ & irrelevant
\end{tabular}

$r$ - Pearson's correlation coefficient.

suggesting that the presented speech therapy tool is best applied at an early age. Crucially, the study revealed - on the basis of Speech Studio voice profiles (see Figure 2) that hearing impaired students exhibit very large variations in voice pitch, up to $90-180 \mathrm{~Hz}$ (with $20 \mathrm{~Hz}$ being the maximum normal value). These results were associated with very large standard deviations (S.D.Fx value in Figure 3), suggesting inherent instability in the fundamental frequency determination process.

More importantly, the evaluation conducted 3 months after the end of the experiment confirmed a high persistence of improvements by students who had access to the computerized therapy workstations (see Table 4).

That leads to the conclusion that the proposed therapy, based on multimedia visualization of speech characteristics with the PCLX Laryngograph Processor, is highly effective, fulfilling one of the primary goals of the research.

Concomitant variables and their influence on the effectiveness of our therapeutic process (see Table 5) proves that intelligence and visual-motor coordination seem to play a significant role. The former is easily explained, since intelligence and mental capacity affect any type of learning process. Concerning the latter, coordination impairments are often correlated with poor perception and lack of motor skills required for voiced speech. Teaching aurally impaired students correct articulation involves both of these effects, which is why visual-motor coordination significantly affects the outcome of therapy. Variables such as learning speed, working memory capacity, forgetfulness, time since onset of hearing loss, and degree of aural impairment proved to be less important. Improvements seemed to depend on the subject's family environment and were largely independent of the age and degree of hearing loss.

The research enables us to conclude that pathological voice pitch characteristics in aurally impaired students are not due to physiological malformation of vocal folds (as shown by graphical analysis). We have also noted that most of our test subjects exhibited symptoms of hyperfunctional dysphonia, with coarse articulation and (in most cases) excessively high pitch.

During the study several general observations were made about speech and articulation therapy, and the outlook for training aurally handicapped children using computerized workstations. Key aspects are interactivity and involvement of students in the teaching process while keeping supervisor interventions to a minimum. It should also be noted that the supervisor was male - a purposeful decision since, according to Porges' polyvagal theory $[13,14]$ male voices are perceived as louder and easier for the child to remember.

Diagnostic studies, similar to the one presented in this paper, could also be performed for students with partial hearing defects and the recipients of cochlear implants. Another possible direction of study is to apply it to aspects other than voice pitch, such as dynamic breathing during voiced speech, action of vocal folds, nasality, articulation, or prosody. The technical capabilities of the PCLX Laryngograph Processor readily support such research, since all the available assessment categories are accompanied by qualitative (graphical) and quantitative (numerical) analysis tools.

\section{Conclusions}

The research has shown that voice pitch therapy, based on multimedia visualization of speech characteristics with the PCLX Laryngograph Processor, is highly effective, fulfilling one of the primary goals of the study. Improvements obtained by students who had access to computerized therapy workstations were highly persistent. Changes in pitch appeared to be most persistent among the youngest students (aged 10), suggesting that the presented speech therapy tool is best applied at an early age. The second goal of the research was also reached, showing that concomitant variables such as intelligence and visual-motor coordination seem to significantly influence the effectiveness of the therapeutic process. 


\section{References:}

1. Korzon A, Plutecka K. Kształcenie zintegrowane uczniów niesłyszących w teorii i praktyce edukacyjnej. Oficyna Wydawnicza IMPULS, Kraków, 2010.

2. Zielińska J: Diagnoza i terapia sprawności ortofonicznej dzieci z uszkodzeniem słuchu wspomagane techniką komputerową. Wydawnictwo Naukowe Akademii Pedagogicznej, Kraków, 2004.

3. Rhoades EA, Chrishom TH. Global language progress with an auditory-verbal therapy approach for children who are deaf or hard of hearing: Volta Review, 2000; 102: 5-25.

4. Blamey PJ, Sarant JZ, Paatsch LE, Barry JG, Bow CP, Wales RJ. Relationships among speech perception, production, language, hearing loss, and age in children with impaired hearing: Journal of Speech, Language and Hearing Research, 2001; 44: 264-85.

5. Tharpe AM, Ashmead DH, Rothpletz AM: Visual attention in children with normal hearing, children with hearing aids, and children with cochlear implants. Journal of Speech, Language and Hearing Research, 2002; 45: 403-13.

6. Horn DL, Davis RAO, Pisoni DB, Miyamoto RT: Development of visual attention skills in prelingually deaf children who use cochlear implants. Ear Hear, 2005; 26(4): 389-408.
7. Schow RL, Nerbonne MA: Introduction to Audiologic Rehabilitation. $5^{\text {th }}$ ed. Boston, MA: Pearson Allyn and Bacon, 2007.

8. Rochette F, Bigand E. Long-term effects of auditory training in severely or profoundly deaf children. The Neurosciences and Music III: Disorders and Plasticity: Annals of the New York Academy of Sciences, 2009; 1169: 195-8.

9. De Raeve L, Anderson I, Bammens M, Jans J, Haesevoets M, Pans $\mathrm{R}$ et al. The listening cube: a three dimensional auditory training program. Clin Exp Otorhinolaryngol, 2012; 5(1): S1-S5.

10. Abberton E, Howard D, Fourcin A: Laryngograph assessment of normal voice: a tutorial. Clinical Linguistic and Fonetics, 1996; 3: 243-59.

11. Fourcin A, Abberton E. Hearing and phonetic criteria in voice measurement: clinical applications. Logoped Phonaitr Vocol, 2008; 33(1): 35-48.

12. Guimaraes, I., Abberton, E: Fundamental frequency in speakers of Portuguese for different voice samples. J Voice, 2005; 19(4): 592-606.

13. Porges SW. Social engagement and attachment: a phylogenetic perspective. Annals New York Academy of Sciences, 2003; 1008: 31-47.

14. Porges SW. The polyvagal perspective. Biol Psychol, 2007; 74: 116-43. 